\title{
Natural background radiation and population dose in China
}

\author{
Pan ZIQIANG*, He ZHENYUM**, Yang YIN***, Guo MINGQIANG****, \\ Cui GUANGZHI*****
}

(Manuscrit reçu le 5 avril 1993)

\begin{abstract}
On the basis of analyzing the data for the natural background radiation level in China, the typical values for indoor and outdoor terrestrial gamma radiation and effective dose equivalents from radon and thoron daughters are recommended. The annual effective dose equivalent from natural radiation to the inhabitant is estimated to be $2.3 \mathrm{mSv}$, in which $0.54 \mathrm{mSv}$ is from terrestrial gamma radiation and about $0.8 \mathrm{mSv}$ is from radon and its short-lived daughters.
\end{abstract}

RÉSUMÉ L'analyse des données sur les niveaux de l'irradiation naturelle en Chine a permis de recommander des valeurs types pour l'irradiation gamma terrestre, à l'intérieur et à l'extérieur des habitations, ainsi que l'équivalent de dose efficace pour les produits de filiation du radon et du thoron. On estime à $2,3 \mathrm{mSv}$ l'équivalent de dose efficace annuel dû à l'irradiation naturelle des habitants, dont $0,54 \mathrm{mSv}$ dû au rayonnement gamma terrestre et environ $0,8 \mathrm{mSv}$ dû au radon et à ses descendants à vie courte.

\section{Introduction}

Natural background radiation levels may change with human practice activities and natural evolution. Strictly speaking, natural background radiation level is time-dependent, without any constant level. In contrast to the very slow natural evolution, changes due to human practices, especially the development of modern industries, are quite a fast process that may occur in a brief space of time. The rapid development of nuclear and other industries in China makes it more necessary to investigate the natural radiation level and to determine its baseline so as to discover probable changes quickly.

Natural radiation level measurements began in the late 50 s carried out by the predecessor of the China Institute of atomic energy (CIAE). Before its heavy-water reactor commissioning, environmental gamma-ray levels and radon/thoron daughter concentrations in air around the area of the institute

\footnotetext{
* Bureau of safety, protection, environment and health, China national nuclear corp. (CNNC), P.O. Box 2102-14, Beijing 100822, China.

** National environmental protection agency, Beijing.

*** China institute for radiation protection, Taiyuan.

**** Beijing Hua-Qing corp., CNNC, Beijing.

*****Institute of industrial hygiene, ministry of public health, Beijing.
} 
had been measured. In the 60 s and afterwards, before operating a new nuclear installation, routine environmental radiation background investigations were always performed, usually lasting 1-2 years. Systematic measurements of environmental radiation and radionuclide level began in the last 70 s and early $80 \mathrm{~s}$ in a larger scale, initiated by CIAE, firstly in the Beijing region and then in other selected areas of the country [1]. Cooperative groups affiliated to the ministry of public health implemented a nation-wide investigation programme in the early $80 \mathrm{~s}[2,3]$. A more carefully designed programme covering the mainland of China launched in 1983 by the National environmental protection agency acquired, with higher confidence, a set of complete data on natural environmental radiation levels and radionuclide contents in the soils of the country $[4,5]$.

\section{Terrestrial gamma radiation level}

\subsection{Outdoor gamma radiation level}

Natural gamma radiation levels in fields and over roads in mainland of China are summarized in Table I. As shown, values reported by reference [6] are considerably higher. As revealed previously [7], the main reason was that these measurements were carried out by a type of $\mathrm{NaI}(\mathrm{Tl})$ scintillation radiometer, model FD-71, which has been proved to have very poor energy dependence $[8,9]$, though a correction factor of 0.5 had already been suggested for FD-71 higher gamma response [10] that undoubtedly diminished the deviation of the results. It is obvious that a constant factor cannot match the diversification of terrestrial gamma ray spectra over different places of the vast China territory. As a matter of fact, two independent sets of site-to-site comparison measurements with both an FD-71 and a pressurized ion chamber were conducted, which showed that in fields the average values obtained with FD-71 after being corrected with the factor of 0.5 were still $6.7 \%$ and $9 \%$ higher than the corresponding ion chamber values, and over roads the higher percentage values were as high as $15.9 \%$ and $15 \%$ [11]. It would not be strange to find that for individual sites the unidirectional departure of FD-71 values from the ion chamber values was even higher than the above average percentages [12]. Comparisons against each province and city were also made between values $[2,4,5]$ through which it was found that provinces or cities having higher average gamma level would present higher ratios of soil concentrations of $U$ and Th to ${ }^{40} \mathrm{~K}$. This fact could perfectly be interpreted by the relatively higher energy response of FD71 to $\mathrm{U}$ - and Th-series than to ${ }^{40 \mathrm{~K}}[8]$.

In view of the significant deviation of the data obtained with FD-71 [2], it is reasonable to use the data listed in Table $I$ for calculating the national average values. As a result, the external gamma radiation dose rates in air are estimated at $62.7 \mathrm{nGy} \mathrm{h}^{-1}$ in fields and $59.4 \mathrm{nGy} \mathrm{h}^{-1}$ over roads. The typical values recommended in fields and over roads are 65 and $60 \mathrm{nGy} \mathrm{h} \mathrm{h}^{-1}$ respectively. 


\subsection{Indoor gamma radiation level}

The results of indoor gamma radiation dose rates in air (Tab. I) ; just as in fields [2] also imply a higher systematical deviation. The average value derived from Table I, excluding reference [2] data, is $93.4 \mathrm{nGy} \mathrm{h}^{-1}$. This value is close to the value of $92.7 \mathrm{nGy} \mathrm{h}^{-1}$, which was calculated in terms of contents of radionuclides in house structure materials [25] under the assumption that materials were made of brick $(46.5 \%)$, cement $(5.1 \%)$, lime $(3.2 \%)$, sand $(34.8 \%)$ and broken stone (10.4\%) [26]. The typical values of radionuclide contents in various building materials are listed in Table II ; they are the most representative values recommended for each material listed in the table.

Based on the analysis above, the national external gamma radiation dose rate indoors recommended is $95 \mathrm{nGy} \mathrm{h}^{-1}$.

TABLE I

Gamma radiation levels in China

Niveaux d'irradiation gamma en Chine

\begin{tabular}{|c|c|c|c|c|}
\hline $\begin{array}{l}\text { Region } \\
\text { R }\end{array}$ & 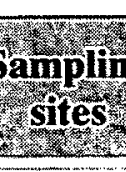 & agedose & Detector & erence \\
\hline In fields & & & & \\
\hline mainland & 38611 & $80.3^{*}$ & $\mathrm{NaI}(\mathrm{Tl})$ & [2] \\
\hline 24 prov. \& cities & 1568 & 67 & $\mathrm{TLD}\left(\mathrm{CaSO}_{4}: \mathrm{Dy}\right)$ & [6] \\
\hline mainland & 8813 & 62.1 & PS \& PIC & [5] \\
\hline mainland & 1961 & $59.0^{*}$ & PS \& PIC & [4] \\
\hline Over roads & & & & \\
\hline mainland & 37727 & 83 & $\mathrm{NaI}(\mathrm{Tl})$ & [2] \\
\hline mainland & 8813 & 61.8 & PS \& PIC & [5] \\
\hline mainland & 2173 & 56.9 & PS \& PIC & [4] \\
\hline Indoors & & & & \\
\hline mainland & 53952 & $119.5^{*}$ & $\mathrm{NaI}(\mathrm{Tl})$ & [2] \\
\hline 22 prov. \& cities & 2452 & $89^{*}$ & $\mathrm{TLD}\left(\mathrm{CaSO}_{4}: \mathrm{Dy}\right)$ & [6] \\
\hline mainland & 8813 & $99.1 *$ & PS \& PIC & [5] \\
\hline maintand & 2766 & $92.1^{*}$ & PS \& PIC & [4] \\
\hline
\end{tabular}

* population weighted average ; PS : plastic scintillator compensated with ZnS ; PIC : pressurized ion chamber.

\section{Radon, thoron and their daughters level}

\subsection{Outdoor concentrations of radon and thoron and their daughters}

In Table III, the concentrations of radon and its daughters in outdoor air are presented for provinces and cities of China where the population amounts to $40 \%$ of the whole country. The population weighted averages of radon concentrations and its daughter equilibrium radon concentrations (EEC) are 11.2 and $6.1 \mathrm{~Bq} \mathrm{~m}^{-3}$ respectively. 
TABLE II

Contents of natural radionuclides in building materials in China Radionucléides naturels dans les matériaux de construction en Chine

\begin{tabular}{|c|c|c|c|c|c|c|}
\hline \multicolumn{7}{|c|}{ 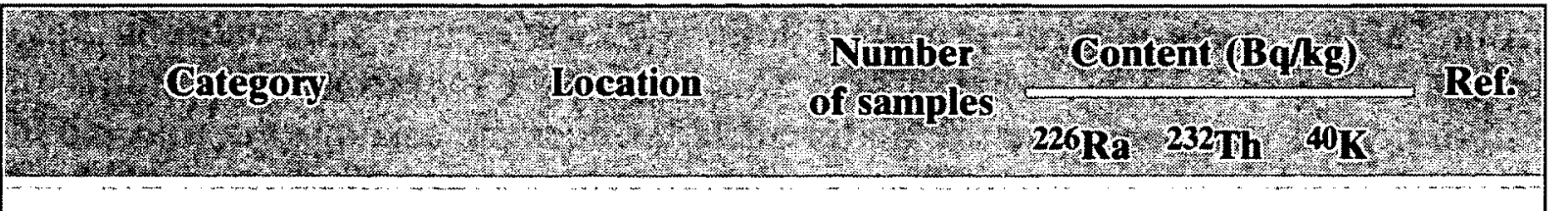 } \\
\hline Clay brick & Various regions & 79 & 58.5 & 73.6 & 551 & [13] \\
\hline Clay brick & Various regions & 26 & 40 . & 52 & 698 & [14] \\
\hline Sintered brick & Various regions & 173 & 61.4 & 63.5 & 667 & [15] \\
\hline Red \& clay brick & Beijing & 5 & 38.0 & 45.4 & 748 & [16] \\
\hline Clay brick & Hebei & 1 & 36 & 48 & 750 & [16] \\
\hline Red brick & Shenzhen & 15 & 81.8 & 109 & 393 & [17] \\
\hline Red brick & Zhejiang & 32 & 62.9 & 85.1 & 544 & {$[18]$} \\
\hline Red brick & Hubei & 22 & 55.5 & 62.2 & 497 & [19] \\
\hline Red brick & Qinchuan, Guangxi & 56 & 78.7 & 52.7 & 558 & [20] \\
\hline Red brick & Hunan & & 42.2 & 60.9 & 421 & [21] \\
\hline Red brick & Sichuan & 2 & 57 & 50 & 448 & [22] \\
\hline Average for brick & & 411 & 54.1 & 63 & 615 & \\
\hline Recommended for brick & & & 55 & 65 & 600 & \\
\hline Broken stone \& pebble & Various regions & 6 & 32.9 & 69.6 & 1047.5 & [13] \\
\hline Rock & Zhejiang & 5 & 69 & 96.2 & 729 & [18] \\
\hline $\begin{array}{l}\text { Recommended for stone } \\
\text { and rock }\end{array}$ & & & 50 & 80 & 900 & \\
\hline Portland cement & Whole country & 47 & 44.0 & 29.6 & 110.3 & $13,23]$ \\
\hline Portland cement & Zhejiang & 26 & 51.8 & 25.9 & 104 & {$[18]$} \\
\hline Portland cement & Hubei & 22 & 59.2 & 42.6 & 218 & [19] \\
\hline Portland cement & Beijing & 4 & 34 & 28 & 320 & [16] \\
\hline Portland cement & Qinchuan, Guangxi & 11 & 45 & 31.6 & 104 & [20] \\
\hline Portland cement & Shenzhen & 16 & 55.2 & 36.4 & 176 & {$[17]$} \\
\hline Portland cement & Sichuan & 3 & 46.9 & 21 & 116 & [22] \\
\hline Portland cement & Shanxi* & 6 & 63.8 & 35.7 & 120 & [24] \\
\hline Average for cement & & & 47.4 & 30.6 & 137.9 & \\
\hline Recommended for cement & & & 50 & 30 & 140 & \\
\hline Lime & Various regions & 8 & 31.8 & 9.6 & 92.9 & [13] \\
\hline Lime & Hubei & 5 & 54.8 & 5.60 & 15.8 & [19] \\
\hline Lime & Zhejiang & 6 & 33.3 & 3.70 & 11.1 & [18] \\
\hline Lime & Shenzhen & 10 & 25.0 & 7.12 & 35.5 & [17] \\
\hline Lime & Beijing & 2 & 3.2 & 0.4 & 35 & [16] \\
\hline Lime & Sichuan & & 0.74 & 2.6 & 4.1 & [22] \\
\hline Average for lime & & & 27.6 & 6.8 & 56.6 & \\
\hline Recommended for lime & & & 25 & 7 & 55 & \\
\hline Sand & Various regions & 7 & 28.1 & 36.6 & 905 & [13] \\
\hline Sand & Hubei & 4 & 30.7 & 18.5 & 815 & [19] \\
\hline Sand & Zhejiang & 7 & 29.6 & 37.0 & 806 & [18] \\
\hline Sand & Shenzhen & 15 & 39.4 & 47.2 & 573 & [17] \\
\hline Sand & Beijing & 4 & 10 & 18 & 790 & [16] \\
\hline Sand & Shanxi & 3 & 3.3 & 39.6 & 1073 & [24] \\
\hline Average for sand & & & 25.2 & 34.4 & 868 & \\
\hline Recommended for sand & & & 25 & 35 & 850 & \\
\hline
\end{tabular}


TABLE III

Outdoor concentrations of radon and its daughters

(EEC obtained through grab sampling techniques)

Concentration, à l'extérieur, en radon et ses descendants et concentration équivalente à l'équilibre (EEC) obtenue par prélèvements ponctuels

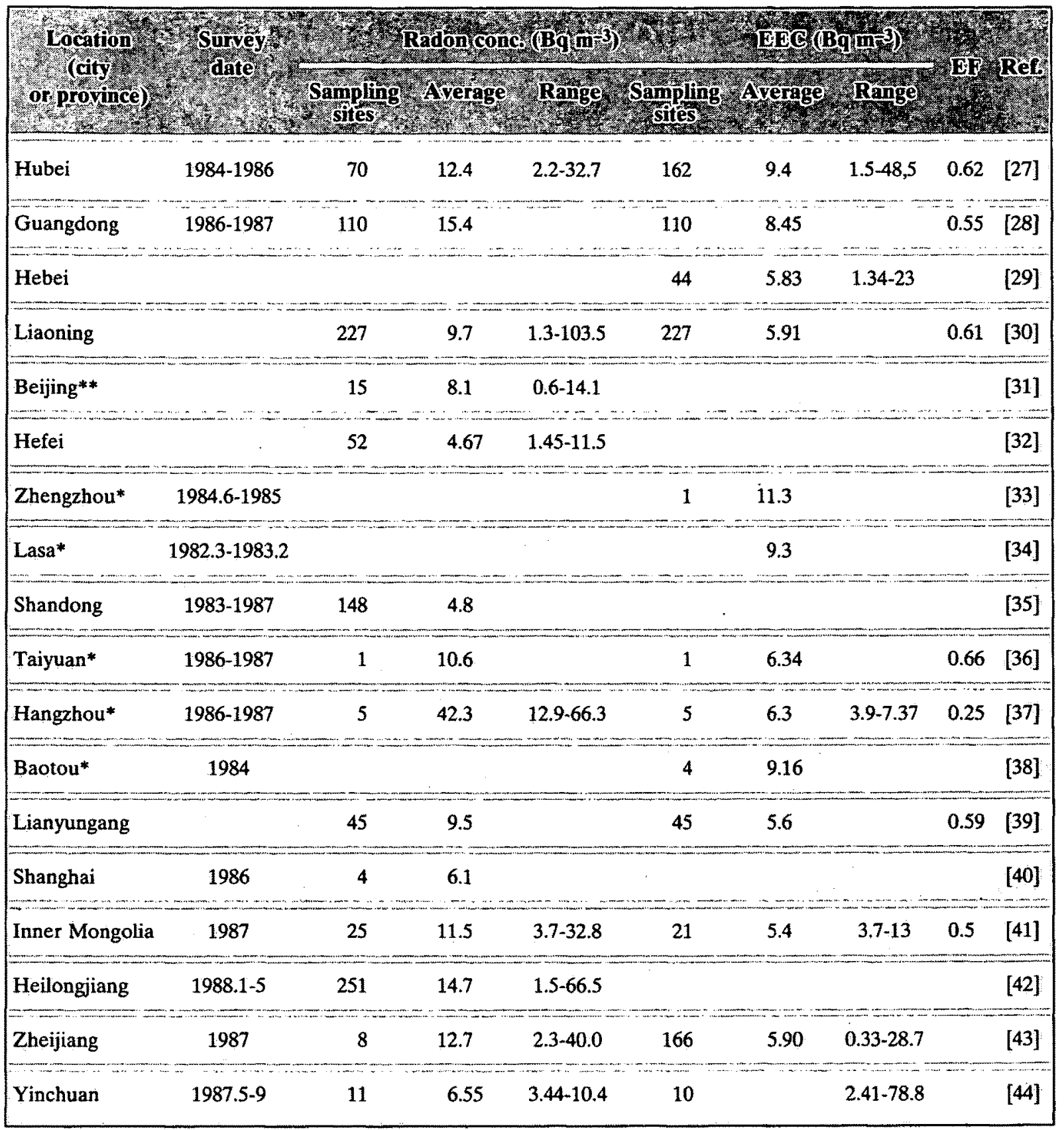

* Average values refer to annual averages. ** Using charcoal canisters for sampling. EF : Equilibrium factor. EEC : Equilibrium equivalent concentration.

The data in Table III were obtained by measurements carried out during the last 10 years using grab sampling techniques. Much attention was paid to the effect of seasonal variations of radon concentrations on the annual ave- 
rages, and efforts were made to arrange the sampling time so as to obtain the best representative results. Nevertheless, these measurements were not performed following one standard procedure; some of them were reported without clearly describing the sampling techniques and/or analysing time, and others had abnormally low equilibrium factors. Consequently, the representativeness and reliability of the data in Table III are different from one another. For the national typical outdoor concentrations of radon and its daughters, 10 and $6 \mathrm{~Bq}$ $\mathrm{m}^{-3}$ are respectively recommended.

The data about thoron and its daughters concentrations in outdoor air are fewer, as shown in Table IV. From these data, the average value of the equilibrium equivalent concentration (EEC) for thoron daughters is estimated at $0.39 \mathrm{~Bq} \mathrm{~m}^{-3}$, and the national typical value of $0.4 \mathrm{~Bq} \mathrm{~m}^{-3}$ is assumed temporally.

TABLE IV

Outdoor concentration of thoron and its daughters

(EEC obtained through grab sampling techniques)

Concentration, à l'extérieur, en thoron et ses descendants (EEC obtenue par prélèvements ponctuels)

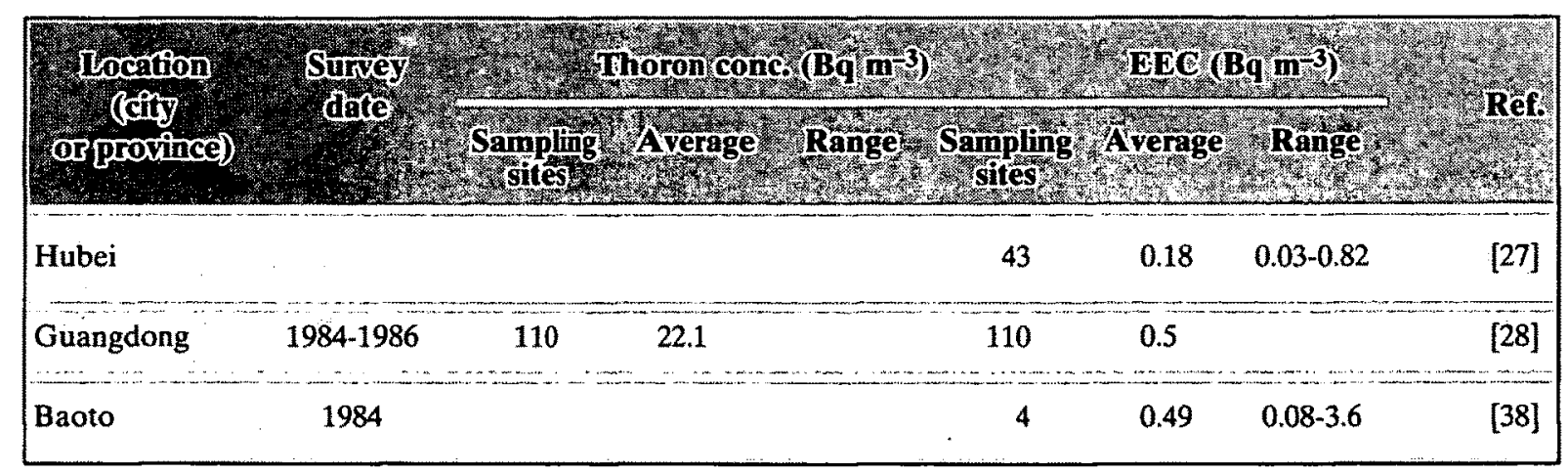

\subsection{Indoor concentrations of radon and thoron and their daughters}

Listed in Table $\mathrm{V}$ are the concentrations of radon and its daughters in indoor air in some provinces and cities of China, where the population amounts to $30 \%$ of the whole country. The population weighted concentration/EEC of radon and its daughters are estimated at 21.4 and $9.9 \mathrm{~Bq} \mathrm{~m}^{-3}$, from which typical values of 20 and $10 \mathrm{~Bq} \mathrm{~m}^{-3}$ respectively may be recommended.

Grab sampling techniques were also adopted for most indoor radon investigations. It is well known that indoor radon and its daughters concentrations are closely related with climate and other factors, such as frequency of open-closed doors and windows. In Table VI are collected some ratios of maximum vs minimum concentration values which are seasonal or monthly averages in different regions. Inter-seasonal ratios are all greater than, but very close to 2 , and the inter-monthly ratios range from 2 to 7 with higher values appearing in the southern part of the country. Owing to consideration of the above factors, the data 
for various regions in Table $\mathrm{V}$ are assumed to be representative to a degree. For the best results, it is better to use instruments giving accumulated radon concentrations, and concentration distributions with locations inside rooms should also be taken into account.

TABLE V

Indoor radon concentration and its daughters (EEC obtained through grab sampling techniques)

Concentration, à l'intérieur des habitations, en radon et ses descendants (EEC obtenue par prélèvements ponctuels)

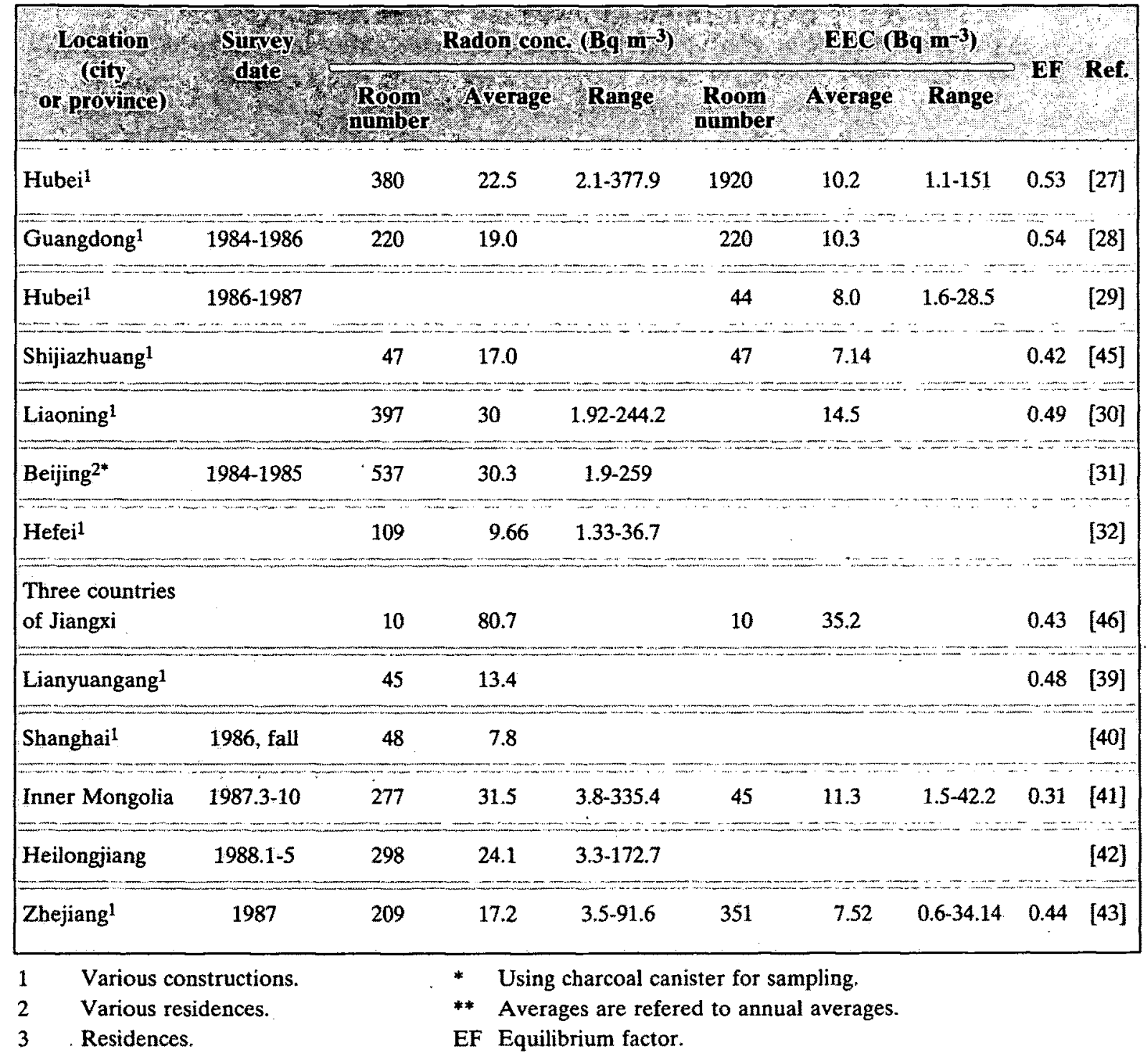

Table VII presents the indoors to outdoors ratios of radon concentrations in different regions, which decrease gradually from North to South, and at the end reach a value a bit higher than 1 in Guangdong province. The reason for this is easily interpreted by different sealings of constructions and different opening time and space of windows and/or doors in various regions. The Guangdong province has more hot and warm days during a year, and conse- 
quently the natural air exchange rate of a room is apparently higher than in the North [49].

Data on indoor thoron concentrations/EECs are fewer in Table VIII. The average EEC value of $0.68 \mathrm{~Bq} \mathrm{~m}^{-3}$ for thoron daughters is obtained, which may be rounded to $0.7 \mathrm{~Bq} \mathrm{~m}^{-3}$, a typical value temporarily recommended.

TABLE VI

Seasonal and monthly indoor radon average concentration, maximum vs minimum

Rapport des concentrations moyennes maximales/minimales, par saison et par mois, en radon, à l'intérieur des habitations

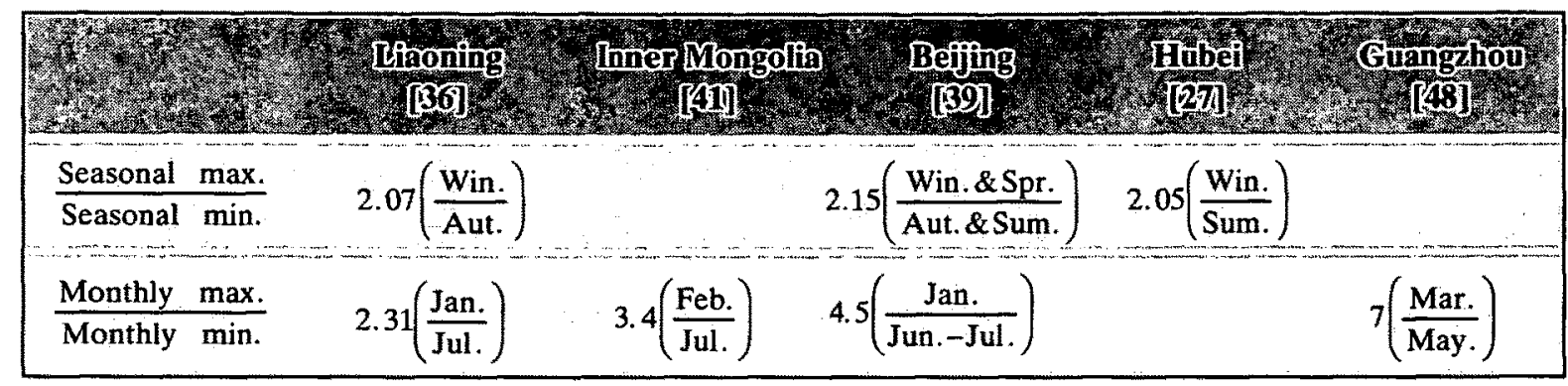

TABLE VII

Indoor vs outdoor radon concentration Rapport des concentrations en radon, intérieur/extérieur

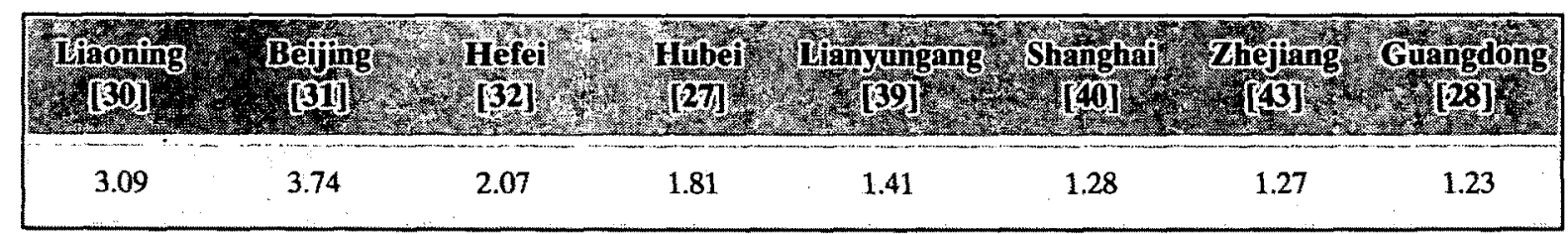

TABLE VIII

Indoor concentration of thoron and its daughters

(EEC obtained through grab sampling techniques)

Concentration, à l'intérieur, en thoron et ses descendants

(EEC obtenue par prélèvements ponctuels)

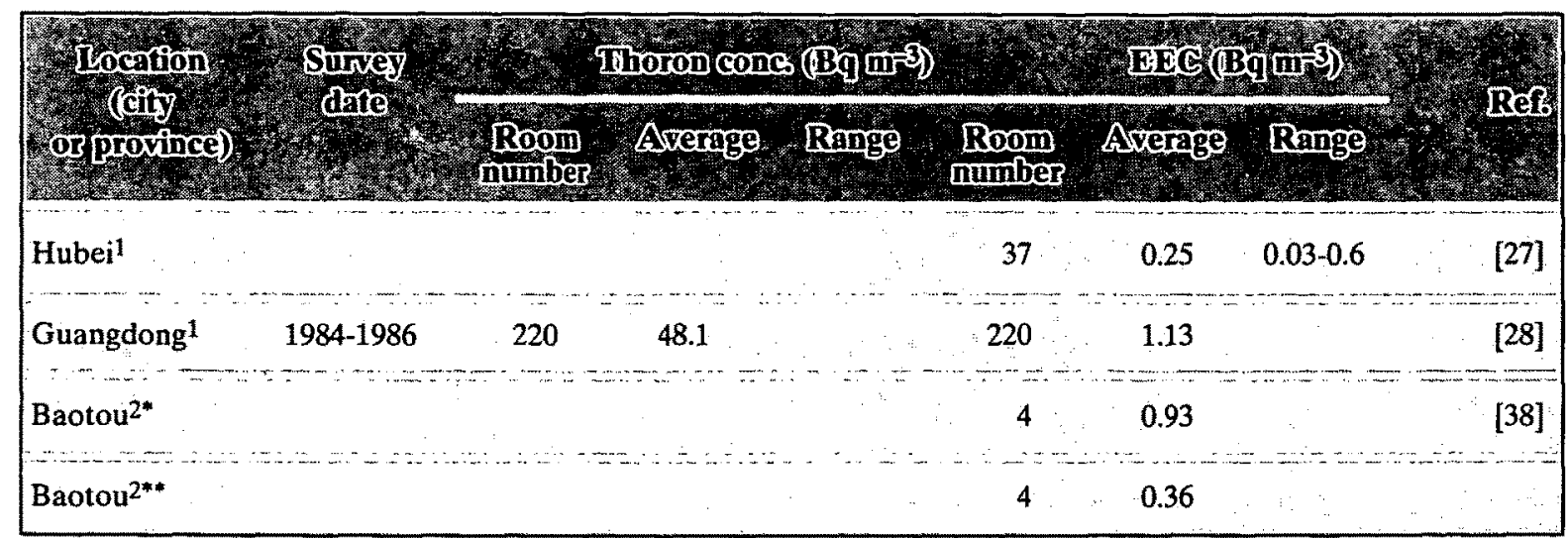

1 Various constructions.

2 Office building.
* Sampling with door and window closed.

** Sampling with window open. 


\section{Dose assessment on natural radiations}

\subsection{External dose assessment}

\section{a) Dose arising from cosmic rays}

The reported per caput annual dose equivalents at sea level from ionizing components of cosmic rays were very close $[2,5,50]$, and the typical value taken here is $250 \mu \mathrm{Sv}$.

Cosmic neutron measurements performed in China have provided some data of neutron flux density both at sea level and at different altitudes $[50,52]$. However, it is hard to take them as a basis for estimating the national population dose. A better approximation is to adopt the value of $55 \mu \mathrm{Sv}$, recommended by the UNSCEAR 1988 report [54].

\section{b) External dose arising from terrestrial gamma radiation}

The per caput annual effective dose equivalent $H\left(\mu \mathrm{Sv} \mathrm{a}^{-1}\right)$ resulting from terrestrial gamma radiation is estimated through the following formula :

$$
H=6.132\left(F_{\mathrm{i}} D_{\mathrm{i}}+F_{\mathrm{o}} D_{\mathrm{o}}\right)
$$

where $F_{\mathrm{i}}$ and $F_{\mathrm{o}}$ are the indoor and outdoor occupancy factors, which are 0.8 and 0.2 according to the investigations in Beijing and other regions $[53] ; D_{\mathrm{i}}$ and $D_{\mathrm{o}}$ are the absorbed dose rates in air $\left(\mathrm{nGy} \mathrm{h}^{-1}\right)$, which, as given above, are 95 and $60 \mathrm{nGy} \mathrm{h}{ }^{-1}$. Substituting these values for $F_{\mathrm{j}}, F_{\mathrm{o}}, D_{\mathrm{i}}$ and $D_{\mathrm{o}}$ in the above formula, the estimated $H$ value is estimated at $540 \mu \mathrm{Sv}$ in China.

\subsection{Internal dose assessment}

a) Dose arising from inhalation of radon and thoron and their short-lived daughters

As aforementioned, the EECs for radon daughters are $6 \mathrm{~Bq} \mathrm{~m}^{-3}$ outdoors and $10 \mathrm{~Bq} \mathrm{~m} \mathrm{~m}^{-3}$ indoors. Adopting the conversion factor of $10 \mu \mathrm{Sv} \mathrm{h}^{-1} \mathrm{~Bq}^{-3}$ suggested by the UNSCEAR 1988 report together with indoor and outdoor occupancy factors of 0.8 and 0.2 , the per caput annual effective dose equivalent resulting fro radon daughters is estimated at about $800 \mu \mathrm{Sv}$.

Similar calculation is used for internal exposure to thoron daughters. Using the given EEC values of $0.4 \mathrm{~Bq} \mathrm{~m}^{-3}$ outdoors and $0.7 \mathrm{~Bq} \mathrm{~m}^{-3}$ indoors and adopting the concentration-to-dose conversion factor recommended by UNSCEAR, the annual effective equivalent dose obtained is $230 \mu \mathrm{Sv}$.

\section{b) Dose arising from internal irradiation of other natural radionuclides}

Considering the cumulative data for other radionuclides is not sufficient for an overall dose assessment in China ; relevant data recommended by UNSCEAR are directly adopted as a basis in the following estimations. The main contributor to the internal dose among other radionuclides is $40 \mathrm{~K}$, which 
is assumed to give $180 \mu \mathrm{Sv}$ per year, equal to the UNSCEAR value. This approximation would not result in apparent deviation, if one recognizes that the metabolic properties of ${ }^{40} \mathrm{~K}$ are not much different in different human bodies. The total internal annual effective dose equivalent by other radionuclides in China is estimated at $420 \mu \mathrm{Sv}$, which is a little higher than the value of $356 \mu \mathrm{Sv}$ given by UNSCEAR. The reasons are as follows :

- the contents of natural radionuclides in China soils are apparently higher than the corresponding UNSCEAR typical values;

- the consequent internal dose arising from intake of foods containing $238 \mathrm{U}$ and ${ }^{232} \mathrm{Th}$ series products is estimated at $58 \mu \mathrm{Sv}$, i.e. higher than the UNSCEAR value [55].

\subsection{Total dose due to natural exposure}

As a preliminary result, the total per caput annual effective dose equivalent resulting from natural radiation in China is estimated at $2.3 \mathrm{mSv}$ (Tab. IX) together with the contribution from different sources.

TABLE IX

Per caput annual effective dose equivalents due to natural radiation in China Equivalent de dose efficace, par individu, dû à la radioactivité naturelle en Chine

\begin{tabular}{|l|c|}
\hline \multicolumn{1}{|c|}{ Source } & Effective dose equivalent \\
\hline $\begin{array}{l}\text { External irradiation } \\
\text { ioninzing part of cosmic rays } \\
\text { neutron of cosmic rays } \\
\text { terrestrial gamma rays }\end{array}$ & 260 \\
\hline Terrestrial gamma rays radiation & 55 \\
radon and its short-lived daughters & 540 \\
thoron and its short-lived daughters & \\
other natural radionuclides & 800 \\
\hline Total & 230 \\
\hline
\end{tabular}




\section{REFERENCES*}

[1] ZIQIANG P, MINGQIANG G. et al. - Report IAE-83-003, 1983.

[2] QILING W., MIAOTING H. - Chin. J. Radiol. Med. Prot., 1985, 5 (Suppl.), 74-76.

[3] SHURONG Z., JINGQUAN P. et al. - Chin. J. Radiol. Med. Prot., 1988, 8 (Suppl. 2), 1-15.

[4] CANSHENG L., JIAJU H. et al. - Investigations of natural radioactive level in five provinces/cities of China. Radiat. Prot., 1986, 6 (4), 241-327.

[5] ZHENYUN H., GUOZHEN L., JIAFU H. et al. - Radiat. Prot., 1992, 12 (2), 81-95.

[6] COOPERATIVE GROUP FOR THE NATIONWIDE SURVEY OF NATURAL RADIATION BACKGROUND. Natural radiation background and assessment. Chin. J. Radiol. Med. Prot., 1989, 9 (4), 225-232.

[7] ZIQIANG P., YIN Y., MINGQIANG G. - Natural radiation and radioactivity in China. Radiat. Prot. Dosim., 1988, 24 (1/4), 29-38.

[8] DEPING L. - Requirements for dosemeters to measure terrestrial gamma radiation (private communication).

[9] JINGYUN L., ZIQIANG P., MINGQIANG G. et al. - Radiat. Prot., 1982, 2 (1), 64-67.

[10] QILIANG W., GUANGZHI C., MIAOTING H. et al. - Chin. J. Radiol. Med. Prot., 1985, 5 (suppl.), 78-81.

[11] ZIQIANG P., YIN Y., MINGQIANG G. - Exposures from natural radiation sources in China. In : Workshop on Occupational and environmental radiation protection, University of Hong Kong, 1987, P1.

[12] JILU H., WENCAI Z., MINGQIANG G. - Radiat. Prot., 1985, 5 (2), 141-144.

[13] XINGSHAN S., ZHONGXING Z. et al. - Chin. J. Radiol. Med. Prot., 1986, 6 (5), 289-293.

[14] Radioactivity limits standard of industral slags used for building materials, proceedings of a Workshop on nuclear energy and environment, Shen Zhen, China, 1988.

[15] QINYUAN Y. - Cement Constr. Mater., 1989, 4, 26.

[16] LIANGING L., HU P. - Radiat. Prot., 1987, 7 (6), 450-455.

[17] SHURON Z., TIANSHAN R. et al. - Chin. J. Radiol. Med. Prot., 1988, 8 (2), 88-93.

[18] YUYAN Q., QINGXINAG S. et al. - Chin. J. Radiol. Med. Prot., 1984, 4 (4), 39-42.

[19] XIONGHUA L., ZHAOHUI Z. - Chin. J. Radiol. Med. Prot., 1985, 5 (4), 271-274.

[20] JIAN L. - Chin. J. Radiol. Med. Prot., 1989, 9(6), 378.

[21] ZHENGGUO Z. - Investigation and dose assessment of the radioactive level in buildings made of cinder bricks of Xiangxi gold mine. J. Radiol. Med. Prot., 1988, 8 (6), 432-436.

[22] MAOliang W., CHENGFANG F. et al. - Radiat. Prot., 1985, 5 (5), 396-389.

[23] QINGXIANG S., YUYAN Q. et al. - Radiat. Prot., 1985, 5 (5), 387-391.

[24] YIAWEN H. et al. - Analyses of uranium, thorium, radium and potassium in slags from Taiyuan iron plant. Radiat. Prot. News, 1984, 4 (4), 33-36.

[25] OECD-NEA, exposure to radiation from natural radioactivity in building materials report by an NEA group of experts. Paris : OCDE, 1979.

[26] Construction handbook. Beijing : Construction industry publisher, 1982.

[27] JIAXING W., BING S. et al. - Chin. J. Radiol. Med. Prot., 1989, 9 (4), 233-240.

* Most references are in chinese, as a consequence full details are not supplied. 
[28] ZHENGHA W., JINXIANG Z. - Radiat. Prot., 1989, 9 (6), 454-459.

[29] LICHUN Y. et al. - Chin. J. Radiol. Med. Prot., 1990, 10 (2), 112-114.

[30] WENBIN M., YAN J. et al. Chin. J. Radiol. Med. Prot., 1990, 10 (3), 159-164.

[31] TIANSHAN R., LIANQING L. et al. - Chin. J. Radiol. Med. Prot., 1986, 6 (4), 223-227.

[32] YUN Z. et al. - Chin. J. Radiol. Med. Prot., 1989, 9 (3), 201-202.

[33] ZHENHUA Z. - Determination of radon daughters in indoor air of Zhengzhou city. J. Radiol. Med. Prot., 1989, 9 (1), 37-39.

[34] XUFENG X. et al. - Chin. J. Radiol. Med. Prot., 1985, 5 (3), 205-207.

[35] LITING S., QINGCHAO G. et al. - Analyses of relationship between environmental radon concentrations and level of radium and $\gamma$-radiation in Shandong province. J. Radiol. Med. Prot., 1990, 10 (2), 78-79.

[36] ZHIHUI Z. et al. - Radiat. Prot., 1989, 9 (5), 379-383.

[37] YUEMING Z. et al. - Concentration level and variation of radon and its daughters in Fuzhou city. Radiat. Prot. News, 1990, 1, 30-33.

[38] HONGYAN L. et al. Radon thoron daughters level in Baoton city. In : Workshop on monitoring and risk assessment of radon and its daughters (Part I), Taiyuan, China, October 1988.

[39] RADIOLOGICAL HYGIENE STATION OF LIANYUNGANG CITY. Environmental radon. Chin. J. Radiol. Med. Prot., 1988, 8 (6), 427.

[40] KUIDON Z. et al. - Investigation of radon level in air in Shanghai region. In : Workshop on monitoring and risk assessment of radon and its daughters (Part I), Taiyuan, China, October 1988.

[41] QINGZHI W. et al. - Proceedings of China-Japan jointly held workshop on environmental radon monitoring, Beijing, 1988.

[42] HEILONGJINAG SANITARY EPIDEMIOLOGICAL STATION. (Same as reference 41), 1988.

[43] JIAN L. et al. - (same as reference 41), 1988.

[44] ZHANCANG L. et al. - (same as reference 41), 1988.

[45] LIANJINAG Z., XIANG L. et al. - Radiat. Prot., 1987, 7 (6), 463-465.

[46] SHIZHONG Q., WENZHI W. et al. - Radiat. Prot., 1985, 5 (6), 446-450.

[47] JIZHONG W. et al. - An assessment of radiation dose to residents from Baogon cement building of blast furnace slag. Radiation Protection Society of China, 1985, P113-118.

[48] ZENHAN W., JINXIANG Z. et al. - Radiat. Prot., 1988, 8 (2), 138-141.

[49] JINGSHU W. et al. - Internal report, 1990.

[50] HUA J., QINGYU Y. - Report CNIC-00361, IAE-0070, 1989.

[51] HIGH ENERGY PHYSICS INSTITUTE RP GROUP, Beijing. Radiat. Prot., 1984, $4(1), 7-11$.

[52] YUELAN W. et al. - Proceedings of the 2nd national symposium of the Radiation protection society, 1983, I-031.

[53] GRNAG B., TENG J. - Investigations on the outdoor residence time and mode for Beijing residents. Radiat. Prot., 1984, 4 (1), 33-37.

[54] UNSCEAR - 1988 Report. New-York : United Nations, 1988.

[55] JINGYUAN Z., HONGDA Z. et al. - Chin. J. Radiol. Med. Prot., 1988, 8 (1), 33-37. 